\title{
Mathematics Connection Ability and Students Mathematics Learning Achievement at Elementary School
}

\author{
Sabina Ndiung $^{1}$, Fransiskus Nendi $^{2}$ \\ ${ }^{1}$ Lecturer of Primary School Teacher Education Department of STKIP St. Paulus Ruteng, Indonesia \\ ${ }^{2}$ Lecturer of Mathematic Education Department of STKIP St. Paulus Ruteng, Indonesia
}

\begin{abstract}
The orientation of education nowadays should be in line with the fulfillment of $21 \mathrm{st}$ century demand which encourage learners to perform the originality of human resources quality. This research aims to know whether there is effect connection mathematics ability toward student's mathematics learning achievement and to know the contribution of connection mathematics ability toward student's mathematics learning achievement at the elementary school. Respondent in this research were 35 students at Watu Weri state elementary school. Proportionate stratified random sampling technique was applied in collecting sample. The research design was ex-post facto. Data were collected through test and documentation. Data were analyzed by linear regression. The research result shows that there was significant effect mathematics connection ability toward student's mathematics learning achievement. The contribution of mathematics connection ability toward students mathematics learning achievement was $21,9 \%$. This result indicates that high or law student's mathematics learning achievement significantly affected by their mathematics connection ability.
\end{abstract}

\section{Introduction}

Recently, education matter in Indonesia continuously becomes a major issue because from year to year there was no significant development in achieving the achievement in international level since from primary school until secondary school. For mathematic learning achievement always fluctuated and occupied at last level [1]. Whereas, on the other hand, Indonesia must be able to compete with 21 st education demand which highlights the quality of human resources that be able to be competent in the global society. Instruction process was blamed in unsucessful of student's learning achievement where more stressed much on result than the process.

Educational demands and skills of the new century require new ways in thinking, learning and teaching. In today's society, there is a need for individuals, who could research and structure the information, with critical thinking skills, could resolve the problems with own knowledge and experience, are creative, open to innovations, and at the same time, with effective communication and cooperation abilities within a group. P21 (2009) called these skills, which the individuals should possess, 21 st Century skills and classified these as "Learning and Innovation Skills," "Life and Career Skills," and "Information Media and Technology Skills." According to Prensky (2001) and Rotherdam and Willingham (2010), 21 st Century skills are not a different set of skills. Every individual is expected to have

\footnotetext{
${ }^{1}$ Punyaku79@gmail.com

2 fransiskusnendisa@gmail.com
} 
creative thinking and problem solving skills that are required for active participation of the individual in the society and the workplace. For students ${ }^{\text {ee }}$ achievements in educational life, they should experience these skills at a very early age. [2].

Theoretical perspectives in mathematics education evolved independently in different regions of the world and different cultural circumstances, including traditions of typical classroom cultures, values, but also varying institutional settings (like the location of mathematics educators in the mathematics or education department, their involvement in pre-service or in-service training, the real and the intended curriculum, the books, etc.)[3]. Since, in mathematics, one way to improve teaching and maximize instructional time is to find and utilize connections among mathematical concepts and ideas. Making these connections takes advantage of the fact that knowledge about one topic comprises part of the knowledge of another. That common knowledge does not have to be taught again, but the teacher does have to recognize and make the connection. Recognizing the connections depends on deep understanding of math concepts and processes [4].

There are six mathematics ability in the process of mathematics instruction according to the NCTM (2014) such as problem solving, reasoning and proof, communication, connections, and representation. Furthermore, in NCTM (National Council of Teacher of Mathematics) affirms that mathematics connection ability is the important factor in understanding mathematics concept [5]. From pre-kindergarten through grade 12, this standard provides two separate components. Firstly, it helps in connection within and among mathematical ideas. Students learn to make connections among mathematical ideas to build a web of connected ideas. Secondly, the standard refers to connections between the real world and other disciplines. Hence, children can see that mathematics have a great role in science, art, and social studies. Briefly, it offers that mathematics should be integrated with other disciplines and the applications related with the real world should be explored. By doing the connection, the mathematics concepts which have been learned can contribute as strong foundation in comprehending a new concept [5],[6].

The fact shows that Indonesian mathematics learning achievement is still far from the expectation. This has been indicated by PISA (Program for International Student Assessment) result in 2015 which focused reading literacy, mathematics, and science shows that Indonesia was at the $69^{\text {th }}$ from 76 nations [1]. The result from TIMSS (Trends in International Mathematics and Science Study) in 2015 also shows that Indonesian students were at the $45^{\text {th }}$ from 48 nations for science and mathematics in which students had low ability for (1) understanding the complicated information, (2) theory, analysis, and problem solving, (3) media usage, procedure and problem solving, and (4) doing the investigation [7].

The notion of 'connections' in mathematics relates both to those that exist: (i) within and between different content areas in mathematics (e.g., within number or between number and measurement); (ii) between mathematics learning and learning in other areas; and (iii) between mathematics and the context within which a child lives, works or plays (Perry \& Dockett, 2008) [8]. Johanning (2010) proposes that, in order to build a coherent curriculum and to foster connections, the big ideas from one topic must be built on in others so that children are given the opportunity to use familiar concepts in new settings [8] .

There were relevant researches conducted by Hendriana, Slamet, \& Sumarmo (2014). The study found that students' prior mathematics ability affected the attainment of mathematical connection ability and its N-Gainas well. Therefore, teacher has to pay more attention on comprehending the prerequisite materialsof mathematics before teaching the more complex materials. The grades of self-confidence of students were still average. Improving students' self-confidence is a continuous process, thus the process of acquiring this trait takes time [9], [10] . Then research conducted by Boyaci \& Atalay (2016). They have found out as a result of the literature review of studies conducted on 21 st Century 
skills, it was determined that there was not a full consensus on the skills that learning individuals should achieve, and there were differences in certain dimensions. Subdimensions of 21 st Century learning and innovation skills could be classified as creativity and innovation, critical thinking and problem solving, cognitive skills or skills related to individual's self, and cooperation and communication or inter-personal skills [2].

Kinniburgh \& Byrd (2008) have found and advocated connecting the teaching of mathematics and social studies; they suggested that using such connections makes deeper understanding for students as they learn. Today we can even use images and photographs to make connections where students can see both the math and social studies concepts within the photos. Newcombe (2013) says, "Science, mathematics, and social studies are deeply spatial subjects. Currently, students who come to class with higher levels of spatial ability take more easily to learning in these areas, but this fact does not mean we cannot teach in a way that maximizes learning for all. Spatial ability can be improved inside and outside the classroom, as well as by instruction in other subject areas, notably the visual arts. Specializing the curriculum by including and explicitly teaching the spatial symbol systems that lie at the heart of science, mathematics, and social studies is an achievable and worthwhile goal [10].

\section{Method}

This is ex-post facto research. Respondent in this research were 35 students who taken from Watu Weri state elementary school. Data were collected through test and documentation. Instrument test was applied in measuring students' mathematics connection ability and documentation was the fifth grade students of their mathematics score in Watu Weri state elementary school in the odd semester of the academic year of 2014/2015. For validity testing, the researcher used the correlation pattern of Pearson product moment. Based on trial result toward 10 item test, it found out that 8 items test were valid. The validity of items test should find the reliability. The reliability of items test, the researchers used Alpha Cronbach's pattern. Data were analyzed by using linear regression with SPSS version of 16.00 for windows. By applying assumption testing was normality testing for distribution and linearity data.

\section{Result and Discussion}

Before finding hypothesis testing which used linear regression, the researchers did the assumption testing like distribution of normality and linearity data. Referenced to research hypotheis analysis result, it found out that coficient $b 2=1,538$ and $b 1=53,250$. By means of data, equality regression sample model which formed in this research was $\widehat{Y}=$ $1,538 \mathrm{X}+53,250$. Furthermore, linear regression coefficient above was tested by using $\mathrm{F}$ testing. In line with this, the following are the data of $\mathrm{F}_{\mathrm{ob}}$ testing with significance grade $(\alpha)$ 0,05 . Obtained that $F_{o b}>F_{c v}$ value was $7,40>4,125$ shows that there was effect mathematics connection ability toward mathematics learning achievement for the fifth grade students at Watu Weri state elementary school. In other word, mathematics connection ability determines students' mathematics learning achievement.

Further analysis is determining the contribution mathematics connection ability toward mathematics learning achievement at the fifth grade students of elementary school. Found determination coefficient $\left(\mathrm{r}^{2}\right)$ was 0,219 means the contribution toward mathematics connection ability toward students' mathematics learning achievement was $21,9 \%$, meanwhile $79,1 \%$ contributed by another variable which was analyzed in this research. If it combines with regression analysis testing, it can be concluded that the variety of students' mathematics learning achievement was $21,9 \%$ can be explained by mathematics connection ability through regression equality 
$\widehat{\mathrm{Y}}=1,538 \mathrm{X}+53,250$. This result indicates that high or law students mathematics learning achievement significantly affected by their mathematics connection ability.

The hypothesis conclusion above indicates empirical proof that there is effect between mathematics connection ability toward students' mathematics learning achievement because mathematics inter-dependence between concept and material and other subjects as well for man's life in everyday such as reasoning, problem solving and creativity development as well. Therefore, in mathematics instruction needs the interdependence between concept and material, mathematics and other subjects, and daily experience, so instruction process can be meaningful. The implication of it, the students is more creative and having better development of mathematics, particularly connection mathematics which support students to achieve better learning achievement.

Individually, mathematics connection ability contributes significant effect toward mathematics learning achievement. Develop the students' ability to connect among concept, material, mathematics usage for other subjects (non mathematics), and definitely support students' learning achievement. Low or high mathematics learning achievement relies on their mathematics connection ability. That is why students are given the opportunities for mathematics exercising mathematics because by developing students' mathematics connection ability may support their deeper mathematics' understanding. NCTM (2000:274) affirms that mathematics connection ability is one of the important point in comprehending mathematics concepts [6]. By comprehending connection, the mathematics concepts which ever learnt may encourage students to understand new concept. The result of this research has been supported by two previous relevant researches such as research conducted by Hendriana, Slamet, \& Sumarmo (2014) where their result shows that students' prior mathematics ability affected the attainment of mathematical connection ability. Then, research conducted by Dixon (2012) which found out that higher scores were possible if students were given time to prepare for the test, as is usually the norm in schools. The intent, however, was to examine students' ability to make connections under impromptu test conditions. 50th percentile were able to connect mathematics and science concepts (16\% and $17 \%$ respectively) learned in the Project Lead the Way (PLTW) curriculum to the problems they that they believed that these concepts were present in the PLTW courses that they had taken. Their recognition of the concepts may have allowed for greater comprehension of the problem, which likely led to more accurate solutions [11]. Thus, mathematics learning achievement must be supported by their mathematics connection ability.

\section{Conclusion}

Reference to the result of the research, it might be concluded that 1) there was significant effect between mathematics connection ability toward mathematics learning achievement of the fifth grade students in Watu Weri state elementary school in the odd semester of academic year of 2014/2015. This conclusion in line with the data of regression significance $\left(\mathrm{F}_{\mathrm{ob}}=7,40>\mathrm{F}_{\mathrm{cv}}=4,125\right)$. The comparison result indicates that mathematics connection ability gives the significant effect toward students' mathematics learning achievement and 2) there was contribution mathematics connection ability toward mathematics learning achievement in the fifth grade students in Watu Weri state elementary school in the odd semester of academic year of 2014/2015. The contribution of mathematics connection ability was $21,9 \%$ toward students' mathematics learning achievement.

This result indicates that mathematics connection ability is an urgent to be done by teacher in instruction process in developing students mathematics learning achivement at primary school by connecting any concepts which are inter-dependence so students are also 
be able to solve the problem. Content of mathematics knowledge is important to be possessed by teacher in order to run mathematics instruction in creating joyful learning atmosphere. By doing such notion, it can be concluded that more and more mathematics connection ability so much more also student's mathematics learning achievement.

Acknowledgments. The researchers would like to gratefully acknowledge a number of people for the help given to them during the process of this research. Primarily, Maksimus Sehadun as the principal of Watu Weri state elementary school for his warm cooperative, Saint Paul Foundation Ruteng in financial support, Prof. A.A.I.N. Marhaeni, for her encouragement to be involved in the journal publication, and students who have involved in this research.

\section{References}

[1] A.Schleicher, "PISA," 2016.

[2] D. Boyaci and N. Atalay, "IJI," vol. 9, no. 1, 2016.

[3] S. Prediger, A. Bikner-ahsbahs, and F. Arzarello, "IJME," vol. 39, no. 2, 2008.

[4] C. C. Molina, "SEDL insights," vol. 1, no. 4, 2014.

[5] NCTM, Six Principles for School Mathematics. 2014.

[6] D. Mehmetlioglu and Y. Ozdem, "IJEMST," vol. 2, no. 1, 2014.

[7] A. Mullis, Ina.V.S. Martin, Michael O. Foy, Pierre Arora, "TIMSS,” 2015.

[8] W. D. Butler, D. Corcoran, T. Farrell, S. Nicmhuirí, M. O. Connor, and J. Travers, Mathematics in Early Childhood and Primary Education, no. 18. NCCA, 2014.

[9] H. Hendriana, "IJE," vol. 8, no. 1, 2014.

[10] J. Graziose and S. L. Ave, "ICTCM," 2013.

[11] R. A. Dixon and R. A. Brown, “JTE,” vol. 24, no. 1, pp. 2-17, 2012. 